\title{
Piecing Together the 'Turkish Puzzle' on Female Labour Force Participation: Comparative Insights from Southern Europe
}

\author{
H. Tolga Bolukbasi (D) and A. Onur Kutlu
}

\begin{abstract}
Southern Europe has seen remarkable turnarounds in female labour force participation (FLFP) over the past four decades. In Turkey, however, scores of women have yet to join the labour force. To address this 'Turkish puzzle', we present comparative data on women's work in Portugal, Spain, Italy and Greece (SE-4) and Turkey. Through Qualitative Comparative Analysis, we identify the factors behind rising FLFP in Southern Europe to explore the prospects for a steeper rise of FLFP in Turkey. We reveal two causal pathways to rising FLFP: (i) left party rule, or (ii) combinations of higher levels of take-up of early education and care, higher levels of tertiary education among women and larger size of service sector employment.
\end{abstract}

\section{KEYWORDS}

Labour market; female employment; gender work inequalities; education and labour market; social care; service sector employment; Qualitative Comparative Analysis (QCA)

One of the most striking socio-economic developments over the post-war period has been an increasing presence of women in labour markets. This overall trend in the OECD area, remarkable as it stands, masks significant variation across different regions. Advanced industrialised countries in North-Western Europe and North America had reduced the gender gap in labour force participation much earlier in the post-war period. South European countries caught up with this trend much later by pulling up female labour force participation (FLFP) as of the 1980s. By the end of the 1990s, most of the countries in Southern Europe, along with their counterparts in Latin America and East Asia, had accomplished significant progress in closing the gender gap (González, Jurado \& Naldini 1999; Cousins 2000; OECD 2002a). Portugal, with already comparatively higher rates, had been leading the way, steadily attracting ever-larger cohorts of women into the labour force. Spain, Greece, and Italy, in time, converged towards Portuguese levels as structural change gained pace (André \& Feio 1999).

Existing research shows time and again that there exist remarkable similarities in labour market and welfare state regimes in Turkey and SE-4 (the South European-4: Portugal, Spain, Italy, and Greece). After all, by 1970, Turkey's FLFP rates were higher than Portugal, Spain, Italy, and Greece as Figure 1 shows. 


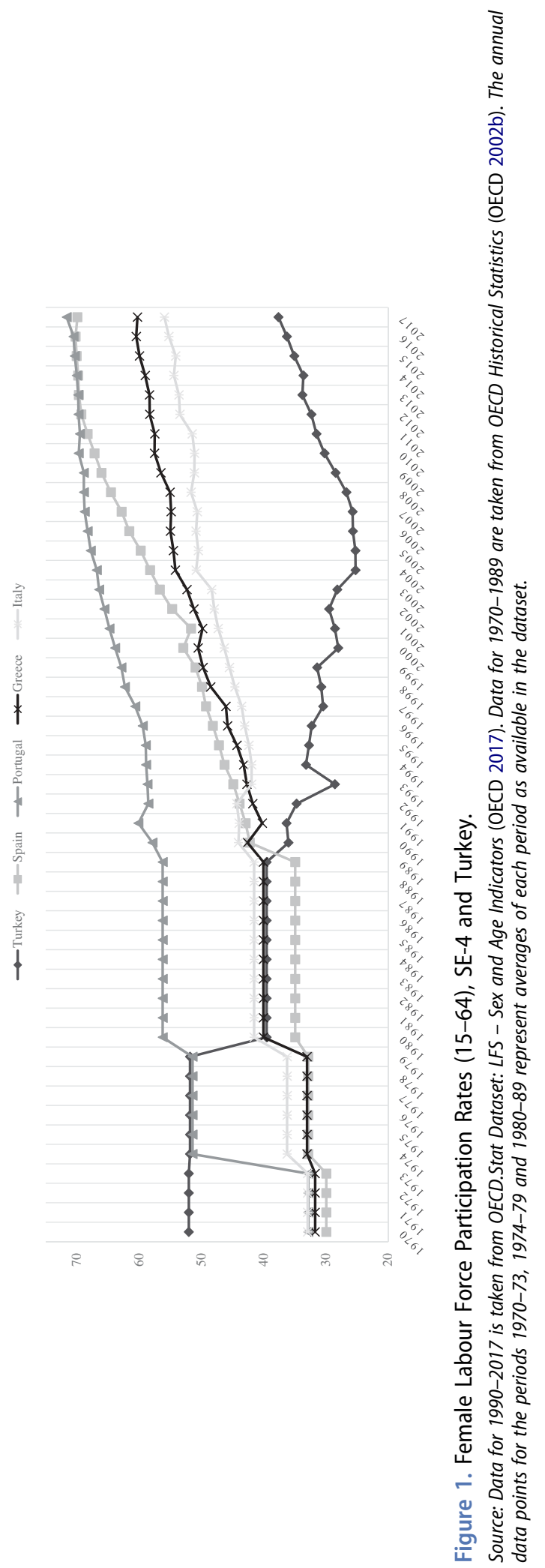


Although FLFP rates remained similar all across Southern Europe including Turkey in the 1970s, Turkey's FLFP began to diverge from other South European countries in the 1980s. This conspicuous divergence continued in even more pronounced ways well into the mid-2000s. Although there has been a recent bounce-back in 2004, the gap between FLFP rates in Turkey and other South European countries remains remarkable. In its Global Gender Gap report, World Economic Forum (2017) ranked Turkey as 131st of 144 countries on the basis of Turkey's extremely low FLFP. This is all the more puzzling for a middle-income country with the 64th largest GDP per capita in the world (IMF 2018).

Policy practitioners as well as scholars were equally puzzled with this sluggish trend. We repeatedly came across references to the 'Turkish puzzle' in policy as well as scholarly research. The World Bank (2009, pp. 6-9) was puzzled not only at the significant decline of FLFP, but also at the very low levels despite favourable developments: 'important structural and social changes', changing 'social attitudes towards working women', women 'becoming more educated', women 'getting married at a later age' and 'substantial drop in fertility rates'. Many scholars including Cindoglu (2011), Memis, Ones and Kızılırmak (2012) and Elver (2012) continued thereafter to present this case as the 'Turkish puzzle'. What is more striking is that Turkey's FLFP ranks lowest not only among Europe, but also worldwide (World Bank 2015). This paper, then, addresses the puzzle, why has FLFP in Turkey remained so sluggish?

Recently, however, FLFP in Turkey seems to be picking up, albeit still sluggishly. In this article, we explore the conditions that may bring sustainable increases in FLFP in Turkey. We hope to gain comparative analytical leverage for prospects for Turkey from similar transitions in SE-4. We identify the conditions we derive from the state-of-the-art on FLFP patterns. Following a complex configurational approach, we rely on qualitative comparative analysis (QCA) to identify all potential causal pathways to rising FLFP in Southern Europe.

We build our argument in five steps. We first provide background information on Turkish labour markets in comparative South European perspective. Second, we review the literature on Turkey which emphasises the role of structural factors and policy regime characteristics pre-empting rising FLFP. Third, we present the comparative literature in order to identify the conditions under which FLFP rises. Fourth, we calibrate and treat these in our QCA as conditions which explain rising FLFP in SE-4 and Turkey. Finally, based on QCA results, the article concludes by discussing the pathways that Turkey may follow.

\section{Turkish labour markets in South European perspective}

\section{Production regime and labour force}

The production regime in Turkey relied on state-led import-substitution industrialisation since the early 1960s. This inward orientation premised on 
protected private industries as well as state economic enterprises. With the 1970s, Turkish economy underwent a structural change through expanding industrial and services sectors. The role of agriculture kept steadily declining. These changes were significant and came much later than those in SE-4. Typical industries were large-scale family holding companies concentrated in a handful of large urban areas. Although producing very high rates of economic growth, this regime went into a bottleneck in the late 1970s. Starting with the early 1980s, the Turkish economy underwent a re-orientation through an export-oriented industrialisation strategy. This development was accompanied by market orientation with the shrinking role of the state in the production regime. By the end of the decade, Turkey had completed the process of integration with world commodity and world financial markets by becoming an open market economy (Bolukbasi 2012).

The new production regime was increasingly characterised by more flexible post-Fordist production arrangements and outsourcing. The structural changes dating back to the 1960s continued with further rounds of industrialisation and expanding services. The dissolution process in the agricultural sector continued. Although the industrial sector was ever expanding, with industrial output as a share of national output steadily rising, gains in industrial employment remained rather limited.

As Table 1 shows, service sector employment expansion (from 32.4 per cent in the 1980s to 51.4 per cent in the 2010s) came at the expense of significant reductions in agricultural employment (from 46.9 per cent in the 1980s to 21.8 per cent in the 2010s). Declining female employment in agriculture (which has traditionally relied heavily on women) (from 78.3 per cent in the 1980s to 34.0 per cent in the 2010s) has been observed mostly by expanding services employment (from 13.1 per cent in the 1980s to 50.1 per cent in the 2010s).

These developments follow SE-4 trends, yet with a significant lag and with still significantly high levels of agricultural employment. Labour force participation trends are in parallel with those in employment. While total labour force participation in Turkey (50.0 per cent in the 2000s and 54.3 per cent in the 2010s) remain significantly lower than SE-4 averages (67.5 per cent in the 2000s and 69.9 per cent in the 2010s) (World Bank 2018b), these differences mask very similar levels for men. It is striking, therefore, that the significant difference in total labour force participation stems entirely from appallingly low participation rates among women.

The low share of public sector employment in the total labour force reflects the fact that the size of the government in Turkey is the smallest in Southern Europe. This figure remains at 12.9 per cent in 2013 in Turkey, which is significantly lower than the SE-4 average of 18.4 per cent in the same year. Although the size of the informal economy has been shrinking in Southern Europe, it shrank in Turkey at a higher rate. Most recent figures show that Turkey's informal economy produces 28.0 per cent of its GDP in the 2010s compared to 23.8 per cent in SE-4. 
Table 1. Employment by Sectors (Total and Female), Size of Informal Economy and Employment in Public Sector in Portugal, Spain, Italy, Greece and Turkey, 1980s-2010s.

\begin{tabular}{|c|c|c|c|c|c|}
\hline & Portugal & Spain & Italy & Greece & Turkey \\
\hline \multicolumn{6}{|c|}{ Employment in agriculture (percentage of total employment) } \\
\hline $1980 \mathrm{~s}$ & 23.4 & 17.1 & 11.4 & 28.4 & 46.9 \\
\hline 1990s & 13.4 & 9.2 & 6.9 & 20.6 & 43.4 \\
\hline $2000 \mathrm{~s}$ & 12.1 & 5.3 & 4.4 & 13.6 & 30.3 \\
\hline $2010 s$ & 9.1 & 4.2 & 3.7 & 12.8 & 21.8 \\
\hline \multicolumn{6}{|c|}{ Employment in services (percentage of total employment) } \\
\hline 1980 s & 41.4 & 49.6 & 54.5 & 43.5 & 32.4 \\
\hline $1990 \mathrm{~s}$ & 53.7 & 59.7 & 60.0 & 55.1 & 34.3 \\
\hline $2000 s$ & 56.5 & 65.1 & 64.8 & 64.0 & 45.2 \\
\hline $2010 \mathrm{~s}$ & 65.9 & 75.4 & 69.1 & 71.0 & 51.4 \\
\hline \multicolumn{6}{|c|}{ Employment in industry (percentage of total employment) } \\
\hline $1980 \mathrm{~s}$ & 35.1 & 33.2 & 34.1 & 28.1 & 27.0 \\
\hline $1990 s$ & 33.0 & 31.1 & 33.1 & 24.3 & 22.3 \\
\hline $2000 s$ & 31.4 & 29.6 & 30.8 & 22.4 & 24.5 \\
\hline $2010 s$ & 25.1 & 20.5 & 27.2 & 16.2 & 26.7 \\
\hline \multicolumn{6}{|c|}{ Employment in agriculture, female (percentage of female employment) } \\
\hline $1980 \mathrm{~s}$ & 28.9 & 15.4 & 12.4 & 37.3 & 78.3 \\
\hline $1990 \mathrm{~s}$ & 15.2 & 7.2 & 6.7 & 24.5 & 71.0 \\
\hline $2000 s$ & 13.0 & 3.6 & 3.5 & 14.9 & 52.2 \\
\hline $2010 s$ & 7.2 & 2.3 & 2.5 & 12.5 & 34.0 \\
\hline \multicolumn{6}{|c|}{ Employment in services, female (percentage of female employment) } \\
\hline $1980 \mathrm{~s}$ & 46.2 & 66.4 & 62.8 & 45.4 & 13.1 \\
\hline $1990 \mathrm{~s}$ & 61.3 & 77.9 & 70.9 & 60.8 & 18.5 \\
\hline $2000 s$ & 67.4 & 83.8 & 78.5 & 74.7 & 33.4 \\
\hline $2010 \mathrm{~s}$ & 77.5 & 89.0 & 83.9 & 79.8 & 50.1 \\
\hline \multicolumn{6}{|c|}{ Employment in industry, female (percentage of female employment) } \\
\hline $1980 \mathrm{~s}$ & 24.9 & 18.1 & 24.8 & 17.3 & 8.6 \\
\hline $1990 s$ & 23.5 & 14.9 & 22.3 & 14.7 & 10.6 \\
\hline $2000 \mathrm{~s}$ & 19.5 & 12.6 & 18.0 & 10.5 & 14.4 \\
\hline $2010 s$ & 15.3 & 8.7 & 13.6 & 7.7 & 15.9 \\
\hline \multicolumn{6}{|c|}{ Size of the informal economy (percentage of GDP) } \\
\hline $1990 \mathrm{~s}$ & 23.2 & 26.8 & 26.2 & 28.8 & 33.8 \\
\hline $2000 \mathrm{~s}$ & 21.9 & 23.0 & 24.0 & 25.5 & 31.3 \\
\hline $2010 \mathrm{~s}$ & 19.8 & 23.7 & 24.7 & 27.2 & 28.0 \\
\hline \multicolumn{6}{|c|}{ Employment in public sector as a percentage of labour force, per cent } \\
\hline 2009 & $\ldots$ & 16.2 & 17.4 & 22.2 & 13.9 \\
\hline 2013 & 16.4 & 17.1 & 17.3 & 22.6 & 12.9 \\
\hline
\end{tabular}

Sources: World Bank (2018b), Medina and Schneider (2018) and OECD (2015)

Note: Data presented for the decades (i.e. 1980s) denotes the averages of the available data belonging to each year within that decade

All of these developments are taking place in labour markets that have traditionally been characterised by deep segmentation. There are two distinct primary and secondary segments in Turkish labour markets. In the primary segment, which accounts for about one-quarter of total employment, employees enjoy highly secure jobs with better pay. This segment is largely composed of 'publicmanufacturing-sector employment, some part of the formal - generally unionised - private sector, and high-end finance and service occupations' (Bolukbasi \& Ertugal 2013, p. 241). In the secondary segment, which accounts for around half of total employment, employees are largely self-employed, working in both agricultural as well as non-agricultural sectors including services and construction. Informal employees, who are not under any protection by labour law, also find 
Table 2. Women's Working Conditions in Portugal, Spain, Italy, Greece and Turkey, 1980s2010s.

\begin{tabular}{|c|c|c|c|c|c|}
\hline & Portugal & Spain & Italy & Greece & Turkey \\
\hline \multicolumn{6}{|c|}{ Part-time employment, females, per cent } \\
\hline $1980 s$ & 13.4 & 11.9 & 17.2 & 12.0 & 18.4 \\
\hline $1990 \mathrm{~s}$ & 14.8 & 14.5 & 20.8 & 13.2 & 17.6 \\
\hline $2000 s$ & 14.3 & 18.4 & 26.9 & 11.4 & 16.5 \\
\hline $2010 \mathrm{~s}$ & 13.1 & 22.4 & 32.3 & 15.5 & 21.5 \\
\hline \multicolumn{6}{|c|}{ Precarious employment, females, all sectors from 15 to 64 , per cent } \\
\hline 2008 & 1.3 & 5.4 & 2.4 & 1.1 & 6.5 \\
\hline 2017 & 2.8 & 5.1 & 3.3 & 1.3 & 5.0 \\
\hline \multicolumn{6}{|c|}{ Temporary employees as percentage of the total number of employees, females, from 15 to 64 years } \\
\hline $1990 \mathrm{~s}$ & 14.8 & 36.1 & 9.9 & 13.1 & $\ldots$ \\
\hline $2000 \mathrm{~s}$ & 22.3 & 33.7 & 13.9 & 14.3 & 11.6 \\
\hline $2010 s$ & 21.8 & 25.7 & 14.7 & 12.7 & 11.5 \\
\hline \multicolumn{6}{|c|}{ Average number of usual weekly hours, females } \\
\hline $1980 \mathrm{~s}$ & 42.4 & 38.7 & 36.8 & 41.5 & $\ldots$ \\
\hline $1990 \mathrm{~s}$ & 39.3 & 37.5 & 36.0 & 40.5 & $\ldots$ \\
\hline $2000 \mathrm{~s}$ & 37.1 & 36.1 & 34.4 & 39.9 & 43.3 \\
\hline $2010 \mathrm{~s}$ & 37.7 & 34.9 & 32.9 & 39.1 & 41.4 \\
\hline
\end{tabular}

Sources: Eurostat (2018), OECD (2018b)

Note: Data presented for the decades (e.g. 1980s) denotes the averages of the available data belonging to each year within that decade

themselves in this segment where they 'move from one precarious job to another' (Bolukbasi \& Ertugal 2013, p. 241). In between these primary and secondary segments are employees in the agricultural sector, who account for nearly another quarter of total employment.

\section{Women's working conditions}

In line with developments in the post-Fordist production regime, incidence of part-time employment among women, as Table 2 shows, has been increasing in Turkey (from 18.4 per cent in the 1980 s to 21.5 per cent in the 2000s). While there does not exist a general pattern in terms of female part-time employment, the recent figure in Turkey remains around SE-4 averages (20.8 per cent in the 2010s). In terms of temporary employment, almost nine out of ten Turkish women are working under permanent contracts. Strikingly, the temporary employment rate in Turkey is currently the lowest in Southern Europe. The average of usual weekly hours shows that in the 2010s, Turkish women (with 41.4 hours) worked the longest week in Southern Europe (where the average was 36.2 hours). Precarious employment among women in Turkey (five per cent in 2017) remains slightly higher than SE-4 averages (3.1 per cent in 2017) sharing the highest rates with Spain (5.1 per cent in 2017).

\section{Skill-level requirements for women}

When educational attainment levels during the 2000s are analysed, the demand structure in terms of skill-requirements for women in the Turkish 
labour market, as Table 3 shows, was similar to the demand structure in Portugal: about two-thirds of Turkish and Portuguese women in employment were low-skilled and less than one-fifth of women in employment were highskilled. The composition of skill requirements was rather different than those in Spain, Italy, and Greece. Although there has not been much change in employment of low-skilled women in Turkey after a decade (59.9 per cent), the share of high-skilled women in employment in Turkey (24.4 per cent) has almost caught up with the shares in Italy (25.5 per cent) and Portugal (28.9 per cent).

In terms of the share of women with tertiary education in the total population of women aged 25 and above, as Table 4 shows, SE-4 countries had similar skill pools in 1970. Hardly any South European women had attained tertiary education back then. In the next five decades, however, the skill pools grew strikingly diverse. Whereas, by 2010, about one out of 20 women had completed tertiary education in Turkey and Portugal (5.4 per cent and 5.1 per cent, respectively), this figure was threefold in Spain (15.9 per cent) and almost fivefold in Greece (24.4 per cent). These figures suggest that while Greece and Spain have succeeded in up-skilling women, Turkey and Portugal failed to do so.

\section{FLFP in Turkey: structural factors and policy regime}

The literature on FLFP in Turkey developed in two waves. In the first wave, structural factors dominate such as the nature of industrialisation, labour market conditions, cultural factors, and production regime characteristics. The second wave emphasised the path-dependent nature of the policy regime shaping female labour force participation patterns.

Table 3. Employment by Educational Attainment Level as Percentage of Total Female Employment in Portugal, Spain, Italy, Greece and Turkey, 2000s and 2010s.

\begin{tabular}{|c|c|c|c|c|c|c|}
\hline & & $\begin{array}{l}\text { Portugal } \\
\quad \%\end{array}$ & $\begin{array}{l}\text { Spain } \\
\%\end{array}$ & $\begin{array}{l}\text { Italy } \\
\%\end{array}$ & $\begin{array}{l}\text { Greece } \\
\quad \%\end{array}$ & $\begin{array}{l}\text { Turkey } \\
\%\end{array}$ \\
\hline \multirow{2}{*}{$\begin{array}{l}\text { Less than primary, primary and lower secondary education } \\
\text { (levels } 0-2 \text { ) }\end{array}$} & $2000 \mathrm{~s}$ & 67.1 & 39.3 & 33.2 & 30.9 & 63.1 \\
\hline & $2010 \mathrm{~s}$ & 46.6 & 30.3 & 25.5 & 21.9 & 59.9 \\
\hline \multirow{2}{*}{$\begin{array}{l}\text { Upper secondary and post-secondary non-tertiary education } \\
\quad \text { (levels } 3 \text { and 4) }\end{array}$} & $2000 \mathrm{~s}$ & 15.8 & 23.3 & 48.2 & 41.4 & 17.5 \\
\hline & $2010 \mathrm{~s}$ & 24.5 & 24.0 & 49.0 & 39.9 & 15.7 \\
\hline \multirow{2}{*}{ Tertiary education (levels $5-8$ ) } & $2000 \mathrm{~s}$ & 17.1 & 37.5 & 18.5 & 27.7 & 19.4 \\
\hline & $2010 \mathrm{~s}$ & 28.9 & 45.7 & 25.5 & 38.2 & 24.4 \\
\hline
\end{tabular}

Source: Eurostat (2018)

Table 4. Women with Tertiary Education, \% (Aged 25 and above).

\begin{tabular}{cccccc}
\hline & Portugal & Spain & Italy & Greece & Turkey \\
\hline 1970 & 0.3 & 0.7 & 0.8 & 1.8 & 0.2 \\
1980 & 0.7 & 3.0 & 1.6 & 4.6 & 0.8 \\
1990 & 2.4 & 4.3 & 3.1 & 7.7 & 4.3 \\
2000 & 4.0 & 11.0 & 5.5 & 12.5 & 4.1 \\
2010 & 5.1 & 15.8 & 7.8 & 24.4 & 5.4 \\
\hline
\end{tabular}

Source: World Bank (2018a) 
In the first wave, most studies emphasise, the centrality of industrialisation explaining declining FLFP: industrialisation that goes hand in hand with urbanisation results in dissolution of the agricultural economy. Scholars highlight structural changes accelerating in the 1980s leading to ever-declining numbers of unpaid family workers - the dominant mode of labour force participation among women - and hence declining FLFP (Buğra \& Keyder 2006). Others emphasise urbanisation processes further depressing FLFP as neither the industrial sector nor services have been able to absorb a large segment of women (Gündüz-Hoşgör \& Smits 2008; Dayioglu \& Kirdar 2010).

A second factor that emerges in this literature is labour market conditions: working conditions and long working hours (Buğra \& Özkan 2012). A third factor concerns cultural determinants such as rising Islamic conservatism, cultural prejudices, social norms on women's work, discrimination against women and traditional patterns of underinvestment in women's education and training (Urla-Zeytinoğlu 1998; Illkkaracan 2012; Goksel 2013; Buğra 2014; Uysal \& Guner 2014; Dildar 2015; Atasoy 2017). Finally, a fourth factor concerns Turkey's dominant production regime, which has been producing jobless growth, resulting in low demand for female labour (Toksöz 2011). In this regime, 'relatively high wages based on the male-breadwinner norm' is seen to lead to low levels of demand for female labour (ilkkaracan 2012).

In addition to this richly diverse literature, a second wave of studies emphasised the path dependent nature of the policy regime with significant policy gaps, aggravating the problem of low FLFP. Inspired by the comparative literature focusing on 'gendering welfare states', these studies emphasise the necessity of social care provision for increasing FLFP in Turkey. This literature shows that Turkey's care regime is quite different from its counterparts in Europe with only low levels of provision of highquality and accessible early childhood education and care arrangements (Toksöz 2007; Kılıç 2008, 2010; Taymaz 2010; İlkkaracan, Kim \& Kaya 2015). Themselves reflections of a highly familial care regime and a masculinised labour market regime, these policies are rooted in conservative gender regimes (ilkkaracan 2013). As an illustration, the most recent figures show that these take-up rates in Turkey (37.2 per cent) are much lower than the SE-4 average of 86.1 per cent (Table 5).

Table 5. Enrolment Rates in Early Childhood Education and Care Services, percentage of 3 to 5-Year-Olds in Portugal, Spain, Italy, Greece and Turkey, 2005-20102016.

\begin{tabular}{lccccc}
\hline & Portugal & Spain & Italy & Greece & Turkey \\
\hline Enrolment rates, 3- to 5-year-olds, \% & & & & \\
2005 & 77.6 & 97.6 & 100.0 & $\ldots$ & 13.4 \\
2010 & 86.9 & 97.1 & 97.6 & $\ldots$ & 27.0 \\
2016 & 89.5 & 96.9 & 94.9 & 63.1 & 37.2 \\
\hline
\end{tabular}

Source: OECD (2018a) 
These two waves of studies emphasising structural factors and the policy regime have provided valuable clues as to why FLFP in Turkey has remained at low levels. However, we do not have a comprehensive model of why FLFP in Turkey did not experience a strong bounce-back followed by a steep rise. We thus turn to the state-of-the-art and explore how the comparative literature explains strong bounce-backs. Here we find that this literature has been broadly busy with chasing after independent causal variables bringing about rising FLFP. They, thus, have been focusing on 'net effects' of these variables, which are taken to be independent from one another. This literature does not explore how different conditions may interact with one another. In doing so, they largely overlook what the QCA approach helps us see: 'how causal conditions may modify each other's relevance or impact' (Ragin 2008, p. 178). Scholars working on Turkey, too, have not interpreted FLFP patterns with the help of a complex configurational approach.

We believe there are substantive as well as methodological grounds for studying rising FLFP through a complex configurational approach. Such a research design would reveal specific causal pathways 'which, if the same conditions are present' will hold for similarly organised cases (Hancké 2009, p. 44). Revealing the interacting nature of the conditions, this configurational design allows for equifinality - 'when there is more than one condition or combination of conditions sufficient for an outcome' (Ragin 2006, p. 14). Only if we follow a configurational research protocol, therefore, can we identify possible pathways for Turkey based on cases in Southern Europe.

\section{The conditions for rising FLFP}

The state-of-the-art on patterns of FLFP features four key factors. In this section, we review this literature and identify potential conditions for explaining rising FLFP. The first two of these conditions (political party configuration and take-up rates of early education and care services) draw on the literature on 'gendered' welfare states. The other two conditions (educational attainment level and relative size of service sector employment) are based on the literature focusing on changing patterns of FLFP.

Among these, first, political party configuration, emerges in this literature as one decisive condition for achieving gender equality in welfare state provision in this literature. State-centred institutionalists argue that left parties initiate and promote policies paving the way for women's empowerment, leading to an increased presence of women in paid labour (O'Connor, Orloff \& Shaver 1999). Similarly, power mobilisation theorists, emphasising the role of partisan politics, argue that the presence and strength of left parties bring about favourable conditions for women's empowerment (Sainsbury 1999; Lambert 2008). Left-wing parties provide more support for working mothers as well as single mothers, compared to right-wing parties which are likely to promote 
traditional family patterns (Wennemo 1994; Gornick, Meyers \& Ross 1997; Bussemaker \& Van Kersbergen 1999; Huber \& Stephens 2000; Ferrarini 2003). Left-wing governments are more service oriented and more gender egalitarian (Huber \& Stephens 2000), support quotas for women (Verge 2013) and promote women's representation in democratic legislatures (Iversen \& Rosenbluth 2008). Just as the welfare state emerged as a power resource in and of itself, increasing FLFP in turn strengthened left parties further through a leftward shift in female voting (Rosenbluth, Salmond \& Thies 2006).

Second, the literature emphasises take-up rates of early education and care services as another key determinant for increasing FLFP (Addis 1999; Thévenon 2016). Welfare states have two aims concerning social care policies: enabling reconciliation of work and family life for parents, and ensuring gender equality in labour markets through childcare arrangements and other family policies. With these aims, welfare states with universal care regimes absorb care responsibilities of women through expanding childcare facilities and allowing rising FLFP (Lewis \& Giullari 2005; Bradshaw \& Finch 2010). Moreover, early education and care centres employ predominantly women, directly contributing to increasing FLFP (Huber \& Stephens 2000).

The literature also features women's educational attainment levels as a key determinant of rising FLFP (Pampel \& Tanaka 1986; Moghadam 1999, 2003). Studies also emphasise the role of educational attainment on FLFP through its effect on the high opportunity costs of non-participation (Hill \& King 1995; Blossfeld 1995; Lesthaeghe 1995; André \& Feio 1999; Bettio \& Villa 1999).

Finally, the literature also emphasises the share of service sector employment in total employment as a significant determinant of rising FLFP. According to the literature, expanding services provides more employment opportunities for women (Goldin 1994; Mingione 1995; Mammen \& Paxson 2008).

We, thus, derive these four conditions that may potentially result in rising FLFP based on this comparative literature: political party configuration, take-up rates of early education and care services, women's educational attainment levels and share of service employment in total employment. We propose a new configurational model of rising FLFP, which we believe, captures the complex causal nature of this phenomenon. These conditions collectively capture all socio-political, economic and cultural factors that are under the sun in the current state-of-the-art.

\section{Research design and method}

In this section, we present the overall research design and method of the study. We first present QCA, the theoretical and methodological rationales for using this method, the cases and timeframe for analysing the conditions bringing about rising FLFP in Turkey. We also discuss how we execute this method. 


\section{Qualitative comparative analysis}

Originally developed by Charles Ragin, QCA is a rich, in-depth analysis of how a set of carefully selected causal conditions produce an outcome of interest. In essence, it rests on a case-oriented approach that 'does not disaggregate cases into independent, analytically separate aspects but instead treats configurations as different types of cases' (Fiss 2010, p. 758). This design is especially 'suitable for analysing situations of causal complexity, that is, situations in which an outcome may result from several different combinations of causal conditions' (Fiss 2010, p. 758). It is therefore useful for social scientists who seek to explain big, large-scale, real world, substantive complex causal conjunctures. It combines the relative strengths of qualitative research with those of quantitative research, and examines particularly small- to medium-N.

In terms of its application, QCA was originally developed through crisp-sets (csQCA) where conditions and outcomes were coded in dichotomous terms: 1 denotes 'fully-in' and 0 denotes 'fully-out'. Since the social reality which researchers addressed is more complex than the world of zeros and ones, Ragin developed fuzzy set QCA (fsQCA). FsQCA allows for studying social reality in more 'finely grained' terms. With fsQCA, researchers have been able to assign multiple 'graded' scores based on substantively meaningful thresholds for conditions and outcomes within the scale between 0 and 1. The 'fuzziness' in this methodology stems from the fact that the boundaries of membership are imprecise.

Regardless of whether one is using csQCA or fsQCA, the method perceives the relations between social phenomena as set relations with the membership scores of cases in sets (Schneider \& Wagemann 2012, p. 3). Membership scores are determined (which is called calibration) by asking questions such as 'does the country score high or low on Y'? (Hancké 2009, p. 80). Upon the assignment of membership scores (which is called the calibration process), researchers build a table, truth table, that summarises the scores for cases and shows the logical possibilities (Hancké 2009, p. 80). In a truth table, each row shows one of the logically possible combinations of the conditions (Schneider \& Wagemann 2012, p. 92).

The next step is carried out by software programmes. These programmes, based on combinations (logical possibilities), yield Boolean equations (Ragin 1987). Once the truth table is prepared, the software programme produces equations representing all logical possibilities. In doing so, the programme follows the procedure of logical minimisation. For example, the algorithm compares rows of the truth table to identify matched pairs, and in case two rows have the same outcome and differ only by only one condition, then, that condition is eliminated since it does not influence generation of the outcome. This Boolean minimisation continues until no further simplification is possible. The ultimate purpose of the formal analysis of the truth table (which the software produces through logical minimisation) is to identify sufficient (and necessary) conditions (Schneider \& Wagemann 2012, p. 91). 
Once the software programme produces equation(s), researchers identify these with necessity and/or sufficiency and/or INUS conditions. Necessity and sufficiency, if present, point to less-complex relationships between conditions and outcomes. It is INUS conditions, if present, however, that reveal the complex causal nature of phenomena. 'INUS' conditions are specific combinations of causal conditions that are insufficient but necessary parts of causal recipes which are themselves unnecessary but sufficient.

\section{Using QCA for analysing rising FLFP in Turkey}

Our novel approach relying on QCA is based on two rationales. Methodologically, first, we observe that accounts focusing on 'net effects' of individual conditions fail to explain lagging FLFP, which is a multi-faceted socio-economic phenomenon couched in complex causal relations. We thus need QCA, an approach best suited to reveal multiple configurational causation, to address this phenomenon. Second, we have a limited number of cases, yet, in substantive terms, they are 'meaningfully comparable' given their shared regime characteristics (Emmenegger, Kvist \& Skaaning 2013). Regression analysis would not be the best method for this study given the relatively small number of cases and the complex interaction effects only a configurational method would help identify. Since QCA was developed mainly for studies with a small and medium number of cases and for the exploration of causal interactions (rather than the 'net effects' of individual variables), it helps us in identifying interaction effects as desired (Rihoux 2006; Avdagic 2011; Emmenegger, Kvist \& Skaaning 2013).

Substantively, we build on the findings of an emerging body of literature on 'institutional complementarities' where interacting institutions may 'create complementarities between policies'. 'Policy measures interacting with each other' in a given area, this literature suggests, increase (or decrease) 'their relative efficiency (or inefficiency)' (Thévenon 2016, pp. 482-483). The extent to which policies are complementary, as we read in the pages of this journal too, also depends on the overall institutional environment, which are nicely illustrated in sister literatures on 'welfare state regimes' (Esping-Andersen 1990), 'labour market regimes' (Esping-Andersen \& Kolberg 1992), 'production regimes' (Huber \& Stephens 2001), 'varieties of capitalism' (Hall \& Soskice 2001) and most recently 'growth regimes' (Hall 2015). Based on these substantive and methodological rationales, therefore, we believe that QCA stands as the ideal approach and method for piecing together the 'Turkish puzzle' on FLFP.

\section{Cases, time frame, and calibration}

The cases analysed in this study are Portugal, Spain, Italy, Greece, (i.e. the SE-4) and Turkey. Representing similar cases, South European welfare states are 
typically clustered together in the literature (Amable 2003; Matsaganis et al. 2003; Ferrera 2016). Most studies on Turkey categorise the Turkish welfare state regime and labour market regime to resemble those in Southern Europe. Common institutional features that are emphasised in this literature include a 'state-influenced' 'Mixed Market Economy'; highly fragmented and hierarchical corporatist system of interest intermediation; adversarial industrial relations with state-controlled wage bargaining; welfare state provision based on occupational and employment status; a high degree of labour market segmentation with high employment protection in the primary segment alongside a highly flexible secondary segment, part of which (informal employment) is not covered under labour law; prominence of self-employment and unpaid family labour; an inadequate level of social protection through splintered social security and social assistance schemes, still pension heavy with an inegalitarian character and the centrality of family in welfare provision (Gough 1996; Gough et al. 1997; Buğra \& Keyder 2006; Grütjen 2008; Gal 2010; Bolukbasi 2012; Bolukbasi \& Ertugal 2013, 2018). Based on similarities of regime-specific characteristics, we thus study all cases in the entire universe of cases in Southern Europe. We know from the literature that analyses of complex causal configurations are valid for most similar and 'meaningfully comparable' cases (Emmenegger, Kvist \& Skaaning 2013). We thus follow this literature and aim at drawing lessons from South European welfare regimes for Turkey.

Concerning the time frame of the study, we use inter-temporal crossnational comparative analysis of two-time periods for all cases. We identify the first period on the basis of low FLFP and the second period on the basis of the transition to significantly higher FLFP. In comparative terms, Period I, which covers the early 1980s, represents comparatively lower levels of FLFP in SE-4. Period II is analysed with recent figures representing highest FLFP levels. As the deviant case, Turkey displays a downward trend in FLFP levels still during the early 2000s. Only after 2004 does Turkish FLFP represent an upturn trend. Therefore, Turkey experienced a 'post-transition' period with a much later and a much weaker rise in FLFP in comparison to her South European neighbours.

\section{Applying fsQCA}

This section presents our results of $\mathrm{fsQCA}^{1}$ based on our calibration, which we explain in the Appendix (available online at https://doi.org/10.1080/13608746. 2019.1582667). We aimed at modelling the conditions under which South European countries experience the transition from lower to higher FLFP. To emphasise this transition, we divided the period under study into two and examined the transition from one to the next where FLFP bounces back. ${ }^{2}$ The outcome of this study is female labour force participation (FLFP in Table 6). For calibrating the outcome, we used labour force participation rates of women between the ages of 15 and 64 based on OECD data (2017). 
We calibrated the four conditions in our analysis as follows. First, the condition political party configuration (LEFT in Table 6), is based on the status of left parties in national parliaments. We thus base our calibration on whether left parties gain a significant number of parliamentary seats. Whether in government or in opposition, this would enable them to steer the political agenda. Our calibration is based on data from the Comparative Manifesto Project Database (Volkens et al. 2018). Second, the condition care is defined as take-up rates of early education and care services (TAKEUP in Table 6). We rely on data on childcare and pre-school education services for children aged 3, 4 and 5, obtained from international organisations and national sources (OECD 1989, 2016; Formosinho \& Formosinho 2008; Hohnerlein 2015). Third, the condition level of tertiary education among women (EDU in Table 6) is defined as the level of tertiary education among women as the percentage of the female population aged $25+$ who has completed tertiary schooling. In calibrating this condition, we rely on World Bank definitions and data (World Bank 2018a). Fourth, the condition, the share of service sector employment (SER in Table 6) captures employment in services as percentage of total employment. We obtained the raw scores of this condition from World Bank's World Development Indicators (World Bank 2018b).

In Tables A2-A7-A10 in the online appendix, we present raw scores for each condition and the outcome. Following the QCA protocol, we conducted an analysis for identifying necessary conditions (Table A12 in the online appendix). We, then, obtained the truth table below (Table 6) by applying the 'truth table algorithm' for the analysis of sufficient conditions.

The truth table represents patterns in the data. First, our truth table shows that three combinations reveal perfect consistency for the outcome (rows 3-5). This implies the sufficiency of these combinations in leading to the outcome. Second, the truth table also presents the number of cases corresponding to each combination. We do not have a row populated with a large number of cases. This suggests that there are diverse patterns resulting in rising FLFP. In fact, the SE-4 in period II shows four different combinations $(1,1,0,1 ; 1,0,1,1 ; 0,1,1,1 ; 1,1,1,1)$, which reveal an in-model variation in rising FLFP rates. Substantively, this suggests that SE-4 countries did not follow one single pattern in raising their FLFP rates. Furthermore, our truth table provides a significant implication for Spain, which presents a marked rise in its FLFP

Table 6. Truth Table of the Analysis.

\begin{tabular}{lccclcccc}
\hline LEFT & TAKEUP & EDU & SER & \multicolumn{1}{c}{ Number of cases } & FLFP & raw consist. & PRI consist. & SYM consist \\
\hline 1 & 1 & 0 & 1 & 3 (Italy-I, Spain-I, Portugal-II) & 1 & 0.805714 & 0.630435 & 0.630435 \\
1 & 0 & 0 & 0 & 2 (Portugal-I, Greece-I) & 1 & 0.816216 & 0.5 & 0.5 \\
1 & 0 & 1 & 1 & 1 (Greece-II) & 1 & 1 & 1 & 1 \\
0 & 1 & 1 & 1 & 1 (Italy-II) & 1 & 1 & 1 & 1 \\
1 & 1 & 1 & 1 & 1 (Spain-II) & 1 & 1 & 1 & 1 \\
0 & 0 & 0 & 0 & 1 (Turkey-II) & 0 & 0.666667 & 0 & 0 \\
0 & 0 & 0 & 1 & 1 (Turkey-I) & 0 & 0.666667 & 0 & 0 \\
\hline
\end{tabular}


rates especially after the 2000s (as Figure 1 above shows). The reason, as our truth table shows, is that Spain in period II uniquely reveals membership in all conditions $(1,1,1,1)$ resulting in an exceptional, secular and steep rise in FLFP.

Third, we examine whether a specific condition is of exceptional significance. For example, the truth table shows that the condition, take-up rates of early education and care services (TAKEUP), has a membership score in period I for Spain and Italy. High take-up rates (0.83 and 1$)$ in these countries in a period when FLFP was lower is striking. The reason seems to be that, as scholars argue (León 2007; Hohnerlein 2009; Scheiwe \& Willekens 2009), governments in both countries expanded pre-school education services to educate younger children. Furthermore, the truth table also shows all SE-4 countries as well as Turkey have membership in services sector employment (SER) in period II. However, although this condition appears to be a significant facilitator in bringing the outcome, our truth table shows that, on the basis of the Turkish case in period II, it cannot singularly lead to rising FLFP. On the basis of the truth table, we conclude that we need to further analyse all the conditions across all cases with the help of the software programme.

Methodologically, Table 6 illustrates possible combinations of the conditions we bring together. Since this study has four conditions, the logically possible combinations are $2^{4}$, which gives us 16 (i.e. $1,1,0,1$ as in the first line). Most of these combinations, however, have no corresponding cases, which are named as 'logical remainders'. We present the number of cases corresponding to each combination in the number column in Table 6. As a critical and required action, we determined the frequency (number of cases) threshold to delete the rows presenting the number of cases below the threshold following the standard procedure QCA methodologists follow. ${ }^{3}$ We determined the frequency threshold as 1 , and deleted the rows with number of cases below 1 . As Table 6 presents, the rows with more than one case are only two, which precludes setting the frequency threshold at a higher level. We follow Ragin (2008) in determining the consistency threshold and discard the values below 0.75 as they indicate substantial inconsistency. ${ }^{4}$

As a following step, we initiated the fsQCA with the truth table above using the software package. Before the analysis is concluded, the prime implicant chart and intermediation solution alert appeared on the screen, which enabled us to use counterfactuals to simplify the complex solution. ${ }^{5}$ In this way, we aim to arrive at an intermediate solution based on our assumption that all conditions (we derive from the literature) collectively contribute to the outcome with their presence. We do so by selecting the option 'present' in the window opened for all conditions. Consequently, we obtained the intermediate solution below:

As Table 7 demonstrates, our analysis reveals two causal pathways (recipes) for increasing FLFP in Southern Europe: (1) increasing salience of left parties OR (2) increasing the size of service sector employment combined with 
Table 7. Intermediate Solution of the Fuzzy Set Qualitative Comparative Analysis.

\begin{tabular}{lccccc}
\hline Solution & LEFT & + & SER*EDU*TAKEUP & $\rightarrow$ & FLFP \\
\hline Raw coverage & 0.853357 & & 0.443463 & & \\
Unique coverage & 0.469965 & & 0.0600707 & & \\
Consistency & 0.741935 & & 1 & & \\
\hline
\end{tabular}

increasing tertiary education among women and increasing enrolment rates of children aged over 3 in childcare or education facilities.

In fuzzy-set notation, the fsQCA is:

\section{LEFT + SER $^{*}$ EDU*TAKEUP $\rightarrow$ FLFP}

The solution consistency of our analysis is 0.754744 while the solution coverage is 0.913428 . Coverage refers to the proportion of membership in the outcome revealed by the solution whereas consistency is the degree to which the fuzzy-set membership scores of all cases in a combination are sufficient for the outcome (Vis 2011). This means that the result of this analysis covers 91 per cent of all cases and 75 per cent of these cases suffices to lead to increased FLFP.

\section{Discussion and conclusions: potential pathways to rising FLFP in Turkey}

The literature on Turkey predominantly emphasises the role of structural factors in explaining low and ever-declining FLFP. This literature concludes that FLFP in Turkey is not likely to pick up until structural changes are complete. A more recent literature added that the path dependent nature of the familial care regime and masculinised labour market regime were accompanied by weak early childhood education and care arrangements. These studies, too, expect that Turkey will not see rising FLFP any time soon. We know that the South European countries that share similar regime characteristics and structural conditions with those in Turkey today have seen rising FLFP decades earlier. What these bodies of literature collectively suggest, however, is that Turkey is at a critical juncture at which FLFP will either pick up or remain stagnant.

We aimed at identifying the factors behind rising FLFP in Southern Europe to explore the prospects for a steeper rise of FLFP in Turkey. We did so by, first, analysing the empirical studies based on cases worldwide to identify determinants of rising FLFP. Second, we treated these determinants as conditions which can potentially explain the outcome of rising FLFP in SE-4 and Turkey. We relied on a cross-national comparative analysis by using QCA where we seek to identify all potential causal pathways to rising FLFP in Southern Europe. We used inter-temporal cross-national comparative analysis of two time-periods in all cases. We identified the first period on the basis of 
comparatively lower FLFP and the second period on the basis of the transition to significantly higher FLFP (with the exception of Turkey which did not experience a significant rise). Third, following the standard procedures in fsQCA, we arrived at equifinality: higher levels of FLFP are brought about by either stronger left party representation in parliaments (which is a sufficient condition) or combinations of higher levels of take-up rates of early education and care (INUS condition), higher levels of tertiary education among women (INUS condition) and larger size of service sector employment (INUS condition). Based on this analysis, therefore, we explain why Turkey lagged behind her South European neighbours concerning FLFP levels: in Turkey, neither of these configurations of conditions is present.

Among the two pathways our analysis reveals, the first is a singularly sufficient condition: the role of left party strength. We borrowed this condition from the literature emphasising partisan politics. State-centred institutionalists and power mobilisation theorists point to the pioneering role of left parties in promoting women's empowerment including facilitating their access to paid labour. Strikingly, however, partisan politics has rarely featured in the literature addressing rising FLFP in Southern Europe. In parallel, we see no emphasis whatsoever on this variable in studies focusing on Turkey. ${ }^{6}$ This article shows that in the cases of Portugal, Spain, and Greece, left parties played significant roles in pulling up FLFP rates.

The case of Spain nicely illustrates the role of the PSOE, Partido Socialista Obrero Español, in encouraging women to participate in the labour force. The PSOE gained a majority of seats in parliament in all three elections held in the 1980 s as well as the elections in 1993, 2004 and 2008. The party played a leading role in increasing FLFP rates through a set of policies. First, the PSOE invested in women-friendly policies through expanding formal childcare services. The government scaled down the school entrance age to three years of age in 1990 (León 2007). Between 1990 and 1997, the enrolment (take-up) among 3-year olds increased from 33,128 to 154,063 . This was accompanied by a remarkable increase in federal funding for preschool and primary education from an average spending of EUR 1,769 per child in 1990 to EUR 2,405 in 1996 (Nollenberger \& Rodríguez-Planas 2015). In 2008, the PSOE initiated the EDUCA3 programme to expand public early education spending further by providing additional (50 per cent) funding from central government to fund new early education facilities (Kuronen et al. 2015). Hence, the prioritisation of early education served to liberate women from socially imposed domestic responsibilities for care, which obviously contributed to rising FLFP.

Second, the PSOE was instrumental in modernising and secularising society through reforming and investing in education and changing traditional attitudes. The government launched a modernisation process through major education reforms during the 1980s and up to the mid 1990s. These reforms included the introduction of Ley Orgánica del Derecho a la Educación (the 
Organic Law of the Right to Education) (Pereyra et al. 2009). Furthermore, as a result of left-party rule, Spanish society has been significantly secularised with remarkable changes in perceptions and attitudes (Moreno \& Marí-Klose 2013). Secularisation of society and changing traditional attitudes, as the literature suggests, contributed to rising FLFP.

Third, the PSOE also promoted policy initiatives on gender equality with feminists gaining influence in policy-making processes. A women's caucus, Mujer y Socialismo, was established within the party. Another major step was passing a law in 2007, which forbid political parties from nominating more than 60 per cent of their candidates from one sex. Such partisan ownership of gender equality encouraged women to pursue roles in paid labour in Spain.

We also show that even when left parties are not powerful in legislatures, policies producing higher levels of tertiary education among women and higher levels of take-up of early education and care services against the background of large service sector employment may bring about rising FLFP in Turkey. It is important to emphasise that since our analysis is based on configurational methods, we can only conclude that all conditions specified in the second path should co-exist at the same time. We thus emphasise the imperative of coordinated policy interventions considering the nature of the second path.

Our study hopes to contribute to the literature in three ways. First, in conceptual terms, we emphasise the role of a particular condition - left parties occupying larger shares of parliamentary seats - in rising FLFP. This condition rarely appears as a causal factor in explaining rising FLFP in the literature on Southern Europe. Second, substantively, we provide a basis for countries sharing regime specific characteristics for learning from one another. We do this through revealing a set of policies which, only if carried out in coordinated ways, can bring scores of women into the labour force. Third, methodologically, we present a model taking into account the complex causal configurational nature of interacting conditions and treat it with fsQCA.

We analyse all countries as two different cases, each representing two periods rather than conducting two separate QCAs for these two periods. Technically, in doing so, our analysis treats each country as two separate countries in the analysis. Although the QCA outcome does not allow longitudinal inference, based on most recent insights from the literature (Rihoux 2006), we form the truth table in this way to gain in-depth understanding on different cases inter-temporally. In doing so, we acknowledge the importance of temporal processes in interpreting complex dynamic phenomena (Hall 2016). With this approach, we hope to offer a modest solution to the static nature of QCA and overcome its limitations in interpreting dynamic processes.

Based on this analysis and assuming that the first path based on left-party strength is currently foreclosed, what lessons can we draw for policy makers in Turkey? First, Turkey may expand delivery of early education and care services in line with the social investment approach increasingly featuring in the EU's policy 
agenda. There has been an expansion in these services in SE-4 also through setting targets for sub-national authorities. Delivery of services is not enough, however. Policy makers should encourage take-up of these services through incentive mechanisms and awareness raising campaigns. Second, in order to increase tertiary education attainment among women, Turkey should reduce its drop-out rates of women in secondary education. Moreover, high-quality tertiary education should be provided with a view to increasing employability of women in the labour force. Finally, although service sector employment has been expanding in Turkey, these jobs have been taken up largely by men, which is in contrast to the experience in SE-4 and elsewhere. An expanding service sector against the background of higher levels of take-up of early childhood education and care services and higher levels of tertiary education among women has the potential to absorb highly educated women into the labour force. All of these policies, however, require a re-orientation in strategic programming of a coherent set of interventions and their effective implementation.

\section{Notes}

1. In data analysis, we rely on fsQCA software version 3.0 developed by Ragin and Davey (2016).

2. Rather than conducting two separate QCA for two periods, we analyse each country as two different cases under two periods, which is one of the distinctive features of this study. Such design is also more suitable for this QCA as it provides a higher number of cases as advised in the literature.

3. By determining frequency threshold, the purpose is to eliminate combinations which do not significantly correspond to the cases to basically simplify the output. The logic is similar while executing consistency threshold.

4. We could have alternatively set the consistency threshold through identifying where the natural breaking point (i.e. largest gap) in consistency scores. This method also gives us the identical threshold of 0.75 .

5. These are tools of fsQCA software for the simplification of the results through intermediate solution assumptions. These assumptions are formed through using counterfactuals through which the 'researcher theorises about how an event or phenomenon would have unfolded had a given causal condition been different' (Legewie 2013, p. 8).

6. While there does not exist any emphasis on the absence of left party strength in explaining low levels of FLFP in Turkey, influential accounts point to the role of the ruling conservative party, cultural factors and patriarchal norms producing an opposite effect (Buğra \& Yakut-Cakar 2010; Buğra 2014; Dildar 2015; Atasoy 2017). However, we argue that, as the South European experience shows, cultural factors and patriarchal norms can be shaped by political parties, which could eventually pave the way for rising FLFP. Hence, we see these factors as intermediary variables, which, in fact, reflect the influence of political parties. 


\section{Acknowledgment}

This article draws, in part, from the research A. Onur Kutlu carried out for his doctoral dissertation project at the Department of Political Science and Public Administration at Bilkent University.

\section{Disclosure statement}

No potential conflict of interest was reported by the authors.

\section{Funding}

This research is supported by the Scientific and Technological Research Council of Turkey (TUBITAK) [Project No: 114K121, Mapping the Turkish Welfare State Through Original Data Generation: A Theoretical and Methodological Contribution to Comparative Welfare State Research and Project No: 1649B031201209, 2211-A National Doctoral Fellowship Programme].

\section{Notes on contributors}

H. Tolga Bolukbasi is Assistant Professor in the Department of Political Science and Public Administration at Bilkent University. His research focuses on comparative public policy, comparative political economy, Europeanisation, comparative labour markets and welfare states. Some of his work has appeared in Journal of European Public Policy, Journal of European Social Policy, Comparative European Politics, European Political Science, and South European Society and Politics.

A. Onur Kutlu is a Ph.D. Candidate in the Department of Political Science and Public Administration at Bilkent University. He received his B.Sc. in Political Science and Public Administration from Middle East Technical University in 2011, and M.A. in International Political Economy from King's College London in 2012. Since 2013, Kutlu has been working in the field of social and economic development through international donor-funded projects.

\section{ORCID}

H. Tolga Bolukbasi (D) http://orcid.org/0000-0001-7465-2309

A. Onur Kutlu (D) http://orcid.org/0000-0001-5953-593X

\section{References}

Addis, E. (1999) 'Gender in the reform of the Italian welfare state', South European Society and Politics, vol. 4, no. 2, pp. 122-149.

Amable, B. (2003) The Diversity of Modern Capitalism, Oxford University Press, Oxford.

André, I. M. \& Feio, P. A. (1999) 'Development and equality between women and men in the Portuguese labour market', South European Society and Politics, vol. 4, no. 2, pp. 54-71.

Atasoy, B. S. (2017) 'Female labour force participation in Turkey: the role of traditionalism', The European Journal of Development Research, vol. 29, no. 4, pp. 675-706. 
Avdagic, S. (2011) 'The conditions for pacts: A fuzzy-set analysis of the resurgence of tripartite concertation', in Social Pacts in Europe: Emergence, Evolution, and Institutionalization, eds S. Avdagic, R. Martin \& J. Visser, Oxford University Press, Oxford, pp. 17-44.

Bettio, F. \& Villa, P. (1999) 'To what extent does it pay to be better educated? Education and the work market for women in Italy', South European Society and Politics, vol. 4, no. 2, pp. $150-170$.

Blossfeld, H. P. (1995) The New Role of Women: Family Formation in Modern Societies, Westview Press, Oxford.

Bolukbasi, H. T. (2012) 'Political economy', in The Routledge Handbook of Modern Turkey, eds M. Heper \& S. Sayarı, Routledge, New York, pp. 341-351.

Bolukbasi, H. T. \& Ertugal, E. (2013) 'Europeanisation of employment policy in Turkey: tracing domestic change through institutions, ideas and interests', South European Society and Politics, vol. 18, no. 2, pp. 237-257.

Bolukbasi, H. T. \& Ertugal, E. (2018) 'Napoleonic tradition, majoritarianism, and Turkey's statist policy style', in Policy Styles and Policy-Making, eds M. Howlett \& J. Tosun, Routledge, New York, pp. 351-374.

Bradshaw, J. \& Finch, N. (2010) 'Family benefits and services', in The Oxford Handbook of the Modern Welfare State, eds F. Castles, S. Leibfried, J. Lewis, H. Obinger \& C. Pierson, Oxford University Press, Oxford, pp. 463-478.

Buğra, A. (2014) 'Revisiting the Wollstonecraft dilemma in the context of conservative liberalism: the case of female employment in Turkey', Social Politics: International Studies in Gender, State \& Society, vol. 21, no. 1, pp. 148-166.

Buğra, A. \& Keyder, Ç. (2006) 'The Turkish welfare regime in transformation', Journal of European Social Policy, vol. 16, no. 3, pp. 211-228.

Buğra, A. \& Özkan, Y. (2012) 'Modernization, religious conservatism and female employment through economic development in Turkey', in Trajectories of Female Employment in the Mediterranean, eds A. Buğra \& Y. Özkan, Palgrave Macmillan, New York, pp. 91-113.

Buğra, A. \& Yakut-Cakar, B. (2010) 'Structural change, the social policy environment and female employment in Turkey', Development and Change, vol. 41, no. 3, pp. 517-538.

Bussemaker, J. \& Van Kersbergen, K. (1999) 'Contemporary social-capitalist welfare states and gender inequality', in Gender and Welfare State Regimes, ed D. Sainsbury, Oxford University Press, Oxford, pp. 15-46.

Cindoglu, D. (2011) Headscarf Ban and Discrimination: Professional Headscarved Women in the Labor Market, TESEV Publications, İstanbul.

Cousins, C. (2000) 'Women and employment in Southern Europe: the implications of recent policy and labour market directions', South European Society and Politics, vol. 5, no. 1, pp. 97-122.

Dayioglu, M. \& Kirdar, M. G. (2010) 'Determinants of and trends in labor force participation of women in Turkey', available online at: http://documents.worldbank.org/curated/en/ 466591468316462301/Determinants-of-and-trends-in-labor-force-participation-of-womenin-Turkey

Dildar, Y. (2015) 'Patriarchal norms, religion, and female labor supply: evidence from Turkey', World Development, vol. 76, pp. 40-61.

Elver, H. (2012) The Headscarf Controversy: Secularism and Freedom of Religion, Oxford University Press, Oxford.

Emmenegger, P., Kvist, J. \& Skaaning, S. E. (2013) 'Making the most of configurational comparative analysis: an assessment of QCA applications in comparative welfare-state research', Political Research Quarterly, vol. 66, no. 1, pp. 185-190. 
Esping-Andersen, G. (1990) The Three Worlds of Welfare Capitalism, Princeton University Press, Princeton.

Esping-Andersen, G. \& Kolberg, J. E. (1992) 'Welfare states and employment regimes', in The Study of Welfare State Regimes, ed J. E. Kolberg, ME Sharpe, New York, pp. 3-35.

Eurostat (2018) Labour Force Survey Series, Detailed Annual Survey Results, Eurostat, Luxembourg.

Ferrarini, T. (2003) 'Parental leave institutions in eighteen post-war welfare states', PhD thesis, Swedish Institute for Social Research.

Ferrera, M. (2016) 'Resemblances that matter: lessons from the comparison between Southern Europe and East Asia', Journal of European Social Policy, vol. 26, no. 4, pp. 374-383.

Fiss, P. C. (2010) 'Qualitative comparative analysis', in Encyclopaedia of Case Study Research, eds A. Mills, G. Durepos \& E. Wiebe, SAGE Publications, California, pp. 758-760.

Formosinho, J. \& Formosinho, J. (2008) System of Early Education/Care and Professionalisation in Portugal, Report Commissioned by the State Institute of Early Childhood Research (IFP) Munich, Germany, available online at: https://www.ifp.bayern.de/imperia/md/content/ stmas/ifp/commissioned_report_portugal.pdf

Gal, J. (2010) 'Is there an extended family of Mediterranean welfare states?', Journal of European Social Policy, vol. 20, no. 4, pp. 283-300.

Goksel, i. (2013) 'Female labor force participation in Turkey: the role of conservatism', Women's Studies International Forum, vol. 41, pp. 45-54.

Goldin, C. (1994) 'The U-shaped female labor force function in economic development and economic history', in Investment in Women's Human Capital and Economic Development, ed P. T. Schultz, University of Chicago Press, Chicago, pp. 61-90.

González, M. J., Jurado, T. \& Naldini, M. (1999) 'Introduction: interpreting the transformation of gender inequalities in Southern Europe', South European Society and Politics, vol. 4, no. 2, pp. 4-34.

Gornick, J., Meyers, M. K. \& Ross, K. E. (1997) 'Supporting the employment of mothers: policy variation across fourteen welfare states', Journal of European Social Policy, vol. 7, pp. 45-70.

Gough, I. (1996) 'Social assistance in Southern Europe', South European Society and Politics, vol. 1, no. 1, pp. 1-23.

Gough, I., Bradshaw, J., Ditch, J., Eardley, T. \& Whiteford, P. (1997) 'Social assistance in OECD countries', Journal of European Social Policy, vol. 7, no. 1, pp. 17-43.

Grütjen, D. (2008) 'The Turkish welfare regime: an example of the Southern European model? The role of the state, market and family in welfare provision', Turkish Policy Quarterly, vol. 7, no. 1, pp. 111-129.

Gündüz-Hoşgör, A. \& Smits, J. (2008) 'Variation in labor market participation of married women in Turkey', Women's Studies International Forum, vol. 31, no. 2, pp. 104-117.

Hall, P. A. (2015) 'How growth regimes evolve in the developed democracies', paper presented at the 22nd International Conference of Europeanists, Paris, 8 July.

Hall, P. A. (2016) 'Politics as a process structured in space and time', in The Oxford Handbook of Historical Institutionalism, eds O. Fioretos, T. G. Falleti \& A. Sheingate, Oxford University Press, Oxford, pp. 31-50.

Hall, P. A. \& Soskice, D. (2001) 'An introduction to varieties of capitalism', in Varieties of Capitalism, eds P. A. Hall \& D. Soskice, Oxford University Press, Oxford, pp. 1-70.

Hancké, B. (2009) Intelligent Research Design: A Guide for Beginning Researchers in the Social Sciences, Oxford University Press, Oxford.

Hill, M. A. \& King, E. (1995) 'Women's education and economic well-being', Feminist Economics, vol. 1, no. 2, pp. 21-46. 
Hohnerlein, E. M. (2009) 'The paradox of public preschools in a familist welfare regime: the Italian case', in Child Care and Preschool Development in Europe Institutional Perspectives, eds K. Scheiwe \& H. Willekens, Palgrave Macmillan, New York, pp. 88-104.

Hohnerlein, E. M. (2015) 'Development and diffusion of early childhood education in Italy: reflections on the role of the church from a historical perspective (1830-2010)', in The Development of Early Childhood Education in Europe and North America Historical and Comparative Perspectives, eds H. Willekens, K. Scheiwe \& K. Nawrotzki, Palgrave Macmillan, UK, pp. 71-91.

Huber, E. \& Stephens, J. D. (2000) 'Partisan governance, women's employment, and the social democratic service state', American Sociological Review, vol. 65, no. 3, pp. 323-342.

Huber, E. \& Stephens, J. D. (2001) Development and Crisis of the Welfare State: Parties and Policies in Global Markets, University of Chicago Press, Chicago.

Illkkaracan, İ. (2012) 'Why so few women in the labor market in Turkey?', Feminist Economics, vol. 18, no. 1, pp. 1-37.

Illkkaracan, ì. (2013) 'Political economy of caring labor, gender and deepening conservatism in a developing economy context: the case of Turkey', Istanbul Technical University, Women's Studies Center Working Paper Series, available online at: http://www.kaum.itu. edu.tr/dosyalar/3013WorkingPaper.WorkFamilyBalance.Turkey.pdf

Illkkaracan, I., Kim, K. \& Kaya, T. (2015) 'The impact of public investment in social care services on employment, gender equality, and poverty: the Turkish case', Research Project Report, Levy Economics Institute of Bard College, August.

IMF (2018) World Economic Outlook Database, Washington, DC, available online at: https:// www.imf.org/external/datamapper/NGDPDPC@WEO/OEMDC/ADVEC/WEOWORLD

Iversen, T. \& Rosenbluth, F. (2008) 'Work and power: the connection between female labor force participation and female political representation', Annual Review of Political Science, vol. 11, no. 1, pp. 479-495.

Kılıç, A. (2008) 'The gender dimension of social policy reform in Turkey: towards equal citizenship?', Social Policy \& Administration, vol. 42, no. 5, pp. 487-503.

Kılıç, A. (2010) 'Gender, family and children at the crossroads of social policy reform in Turkey: alternating between familialism and individualism', in Children, Gender and Families in Mediterranean Welfare States, eds M. Ajzenstadt \& J. Gal, Springer, Dordrecht, pp. 165-179.

Kuronen, M., Kröger, T., Antón-Alonso, F., Cucca, R., Escobedo, A., Jensen, P. H. \& Sabatinelli, S. (2015) 'The relationships between local and national childcare policies-a comparison of Nordic and Southern European cities', in Local Welfare Policy Making in European Cities, eds D. Kutsar \& M. Kuronen, Springer, Dordrecht, pp. 119-134.

Lambert, P. A. (2008) 'The comparative political economy of parental leave and child care: evidence from twenty OECD countries', Social Politics: International Studies in Gender, State \& Society, vol. 15, no. 3, pp. 315-344.

Legewie, N. (2013) 'An introduction to applied data analysis with qualitative comparative analysis', Forum Qualitative Sozialforschung/Forum: Qualitative Social Research, vol. 3, no. 14, Art. 15.

León, M. (2007) 'Speeding up or holding back? Institutional factors in the development of childcare provision in Spain', European Societies, vol. 9, no. 3, pp. 315-337.

Lesthaeghe, R. (1995) 'The second demographic transition: an interpretation', in Gender and Family Change in Industrialised Countries, eds K. Mason \& A. M. Jensen, Clarendon Press, Oxford, pp. 17-62.

Lewis, J. \& Giullari, S. (2005) 'The adult worker model family, gender equality and care: the search for new policy principles and the possibilities and problems of a capabilities approach', Economy and Society, vol. 34, no. 1, pp. 76-104. 
Mammen, K. \& Paxson, C. (2008) 'Women's work and economic development', Journal of Economic Perspectives, vol. 14, no. 4, pp. 141-164.

Matsaganis, M., Ferrera, M., Capucha, L. \& Moreno, L. (2003) 'Mending nets in the South: anti-poverty policies in Greece, Italy, Portugal and Spain', Social Policy \& Administration, vol. 37, no. 6, pp. 639-655.

Medina, L. \& Schneider, F. (2018) 'Shadow economies around the world: what did we learn over the last 20 years?', IMF Working Papers, no. 18/17.

Memis, E., Ones, U. \& Kızılırmak, B. (2012) 'Housewifisation of women: contextualizing gendered patterns of paid and unpaid work', in Gender and Society in Turkey, eds A. Y. Elveren \& S. Dedeoğlu, I.B.Taurus, London, pp. 87-102.

Mingione, E. (1995) 'Labour market segmentation and informal work in Southern Europe', European Urban and Regional Studies, vol. 2, no. 2, pp. 121-143.

Moghadam, V. (1999) 'Gender and globalization: female labor and women's mobilization', Journal of World-Systems Research, vol. 5, no. 2, pp. 366-389.

Moghadam, V. (2003) Modernizing Women: Gender and Social Change in the Middle East, Lynne Rienner Publishers, London.

Moreno, L. \& Marí-Klose, P. (2013) 'Youth, family change and welfare arrangements', European Societies, vol. 15, no. 4, pp. 493-513.

Nollenberger, N. \& Rodríguez-Planas, N. (2015) 'Full-time universal childcare in a context of low maternal employment: quasi-experimental evidence from Spain', Labour Economics, vol. 36, pp. 124-136.

O'Connor, J. S., Orloff, A. S. \& Shaver, S. (1999) States, Markets, Families: Gender, Liberalism and Social Policy in Australia, Canada, Great Britain and the United States, Cambridge University Press, Cambridge.

OECD (1989) Education in OECD Countries, 1986-87, OECD Publications, Paris.

OECD (2002a) OECD Employment Outlook, OECD, Paris.

OECD (2002b) OECD Historical Statistics, 1970-2000, OECD Publications, Washington.

OECD (2015) Government at a Glance 2015, OECD Publications, Paris.

OECD (2016) OECD Family Database, available online at: http://www.oecd.org/els/family/ database.htm

OECD (2017) Labour Force Survey by Sex and Age - Indicators, OECD.stat, available online at: https://stats.oecd.org/Index.aspx?DataSetCode=LFS_SEXAGE_I_R.

OECD (2018a) OECD Family Database, available online at: http://www.oecd.org/els/family/ database.htm

OECD (2018b) Part-Time Employment Rate - Indicator, OECD.stat, available online at: https:// stats.oecd.org/

Pampel, F. C. \& Tanaka, K. (1986) 'Economic development and female labor force participation: a reconsideration', Social Forces, vol. 64, no. 3, pp. 599-619.

Pereyra, M. A., Faraco, J. C. G., Luzón, A. \& Torres, M. (2009) 'Social change and configurations of rhetoric: schooling and social exclusion-inclusion in educational reform in contemporary Spain', in International Handbook of Comparative Education, eds R. Cowen \& A. M. Kazamias, Springer, Dordrecht, pp. 217-238.

Ragin, C. C. (1987) The Comparative Method: Moving beyond Qualitative and Quantitative Strategies, University of California Press, Berkeley.

Ragin, C. C. (2006) 'Set relations in social research: evaluating their consistency and coverage', Political Analysis, vol. 14, no. 3, pp. 291-310.

Ragin, C. C. (2008) Redesigning Social Inquiry: Fuzzy Sets and Beyond, University of Chicago Press, Chicago.

Ragin, C. C. \& Davey, S. (2016) Fuzzy-Set/Qualitative Comparative Analysis 3.0, Department of Sociology, University of California, Irvine, CA. 
Rihoux, B. (2006) 'Qualitative comparative analysis (QCA) and related systematic comparative methods: recent advances and remaining challenges for social science research', International Sociology, vol. 21, no. 5, pp. 679-706.

Rosenbluth, F., Salmond, R. \& Thies, M. F. (2006) 'Welfare works: explaining female legislative representation', Politics \& Gender, vol. 2, no. 2, pp. 165-192.

Sainsbury, D. (1999) Gender and Welfare State Regimes, Oxford University Press, Oxford.

Scheiwe, K. \& Willekens, H. (2009) 'Introduction: path-dependencies and change in childcare and preschool institutions in Europe-historical and institutional perspectives', in Child Care and Preschool Development in Europe Institutional Perspectives, eds K. Scheiwe \& $\mathrm{H}$. Willekens, Palgrave Macmillan, New York, pp. 1-22.

Schneider, C. Q. \& Wagemann, C. (2012) Set-Theoretic Methods for the Social Sciences: A Guide to Qualitative Comparative Analysis, Cambridge University Press, Cambridge.

Taymaz, E. (2010) 'Growth, employment, skills and female labor force', State Planning Organization and World Bank Welfare and Social Policy Analytical Work Program Working Paper 6, State Planning Organization, Ankara.

Thévenon, O. (2016) 'Do "institutional complementarities" foster female labour force participation?', Journal of Institutional Economics, vol. 12, no. 2, pp. 471-497.

Toksöz, G. (2007) Women's Employment Situation in Turkey, International Labour Office, Ankara.

Toksöz, G. (2011) 'The state of female labour in the impasse of the neo-liberal market and patriarchal family', in Gender and Society in Turkey, eds S. Dedeoğlu \& A. Y. Elveren, I.B. Tauris, London, pp. 47-64.

Urla-Zeytinoğlu, I. (1998) 'Constructed images as employment restrictions: determinants of female labor in Turkey', in Deconstructing Images of 'The Turkish Woman', ed Z. Arat, St. Martin's Press, New York, pp. 183-197.

Uysal, G. \& Guner, D. (2014) 'Culture, religiosity and female labor supply', Working Papers 013, Bahcesehir University, Betam, İstanbul.

Verge, T. (2013) 'Regulating gender equality in political office in Southern Europe: the cases of Greece, Portugal and Spain', Representation, vol. 49, no. 4, pp. 439-452.

Vis, B. (2011) 'Under which conditions does spending on active labor market policies increase? An fsQCA analysis of 53 governments between 1985 and 2003', European Political Science Review, vol. 3, no. 2, pp. 229-252.

Volkens, A., Krause, W., Lehmann, P., Matthieß, T., Merz, N., Regel, S. \& Weßels, B. (2018) The Manifesto Data Collection. Manifesto Project (MRG/CMP/MARPOR). Version 2018b, Wissenschaftszentrum Berlin für Sozialforschung (WZB), Berlin.

Wennemo, I. (1994) Sharing the Costs of Children: Studies on the Development of Family Support in the OECD Countries, Almqvist \& Wiksell, Stockholm.

World Bank (2009) 'Social and economic benefits of more and better job opportunities for women in Turkey', available online at: http://siteresources.worldbank.org/ECAEXT/ Resources/Turkey_FemaleReport_3_pager_final_final.pdf=

World Bank (2015) 'Supply and demand for child care services in Turkey', Report No. 98884TR, Washington, DC.

World Bank (2018a) 'Education Statistics', available online at: http://databank.worldbank. org/data/reports.aspx?source=education-statistics- -all-indicators

World Bank (2018b) 'World development indicators', available online at: http://databank. worldbank.org/data/reports.aspx?source=2\&series=SL.SRV.EMPL.ZS\&country=

World Economic Forum (2017) 'The Global Gender Gap Report 2017', available online at: https://www.weforum.org/reports/the-global-gender-gap-report-2017 